\title{
THE CONCILIATORY \\ REBELS: ASPECTS \\ OF CONTEMPORARY THAI LITERATURE
}

\section{Chetana Nagavajara ${ }^{1}$}

In the heat of the period of "democratic boom" between 1973 and 1976, many Thai literary pundits were setting high hopes on literature as an instrument of social and political change. That literature was thus conceived is, strictly speaking, nothing startlingly new, for even traditional literature was never completely divorced from practical purposes, as may be witnessed from the didactic strain that ran through classical Thai literature. ${ }^{2}$ Nevertheless, it would be simplistic to assume that the "revolutionary" efforts of the Thai litterateurs during the afore-mentioned period can readily be subsumed under the traditional didactic bent characteristic of Thai literature, for in the first place, the acerbity of these "revolutionary" works distinguishes them from traditional literature, and in the second place, there is denying that their markedly "instrumental" nature was, in many respects, inspired by illustrious Marxian examples from Eastern Europe and particularly from East Asia, where literary reform and radical sociopolitical change went hand in hand.

1 Emeritus Professor of German, Silapakorn University, Thailand.

2 Chetana Nagavajara. "Literature in Thai Life:

Reflections of a Native." South East Asia

Research, Vol. 2, No.1, March 1994.
It is not the $1973-76$ period on which I shall concentrate my analysis in the present essay. More interesting are those works that arose during the period following the counterrevolution of 1976, paradoxically a period of political doldrums! These works are of particular interest to me for a number of reasons. First, they do prove some significant points about the relationship between literature and its socio-political context. A political defeat does not necessarily engender a defeatist acquiescence on the part of progressive writers, for social consciousness and a humane sense of commitment could never be easily obliterated from the minds of responsible artists, and for that matter, of responsible citizens in general. As the poet Komthuan Khanthanu appositely puts it, a "consciousness of a rebel" was always present. Secondly, the years following those political upheavals provided our young writers with an occasion to ponder deeply over the national tragedy and perhaps also over the mistakes committed by their like-minded brethens, and consequently to look for better ways for the future. Thirdly, our young writers were shrewd enough to know that self-censorship was the only way to survive (physically and artistically), and if manipulated with skills, could go to produce works of great subtlety and finesse. Fourthly, and this may be a controversial point, the maturation process of a writer could be accelerated through an 
exposure to an intense emotional experience, especially when this turned out to be more than just a "personal" experience in the normal sense, but a "collective" experience shared by a great many fellow-sufferers! Fifthly, that literary creation should serve as a kind of moral purge, resulting in a more conciliatory philosophical positioning, is a phenomenon that has to be viewed against a broader background of Thai literary tradition and its commitment to the Buddhist doctrine.

The majority of the works that I propose to study in the present essay may be subsumed under the rubric "literature of social consciousness" in line with the well-known Thai P.E.N. Anthology: Short Stories and Poems of Social Consciousness (1984). There is no denying that this type of literature may not have a very wide readership. It is, furthermore, doubtful whether this literature of social consciousness has contributed towards the awakening of a new social awareness on the part of its readers or bringing about constructive change in Thai society. I have elsewhere ${ }^{3}$ spoken of the "impotence" of Thai literature in terms of its role in sociopolitical transformation, for its chief function has been more of a spiritual appeasement. The same observation applies to the works we are considering here.

As a starting point, it may be worthwhile to make a few remarks about the authors themselves. They were mostly young writers in their twenties and thirties. But it would be unfair to brand them, from the outset, as brash and immature, for they had had the kind of experience whose intensity and acerbity far

\footnotetext{
${ }^{3}$ Ibid., pp. 12-20.
}

surpassed that of the earlier generations of Thai writers. They had lived through the "golden age" of Thai democracy, and they themselves may either have made history, or at least may have witnessed how history was made. Expressed in more radical terms, we can say that in spite of their youthful age, they had gone through two "killing fields" (i.e. in 1973 and 1976). Those experiences must have made a strong emotional impact on them. Critics have observed that some of these writers were capable of creating just one major work which turned out to be a real tour de force, and after that lapsed into a kind of artistic aridity, as if all the spiritual and emotional resources had been used up for that one single work. This is particularly true of Chart Kobchitti, whose works I have analysed in an earlier study. ${ }^{4} \mathrm{~A}$ more optimistic view of the phenomenon would be that this was perhaps not a matter of spiritual or emotional "drying-up", but a mere hiatus in a continuous pursuit of new expressions. Be that as it may, let us look at the observation made by the editor of the above mentioned Thai P.E.N. Anthology:

A close examination of literary works, particularly poems and short stories, within the last six years shows that although the "literature of

\footnotetext{
${ }^{4}$ Chetana Nagavajara. "Spatial Concentration and Emotional Intensity. Inspirations from Sartre and Camus in the Works of a Contemporary Thai Novelist." In Proceedings of the XIIth Congress of the International Comparative Literature Association. München: Iudicium, 1990, Vol. 4, pp. 291-299. His latest novel Time (wela) (1994), a minute description of life in an old people's home, represents a totally new direction, an elegiac, existential statement.
} 
social justice" may have suffered a setback right after the political upheaval in 1976, it did not take long for the generation of writers to pick up the banner and resume their forward march. Imbued with deep sympathy for the common man and passion for social justice and willing to experiment with new techniques and styles, these young writers have been successful in bringing the "literature of social justice" to the fore. $^{5}$

I would like to add in this connection that the "rebels" did not, therefore, give up their rebellious cause, but in some ways became conciliatory rebels, for reasons which will be explained in the present essay.

The theme of social justice or injustice, singled out by the Thai P.E.N. editor as the crux of the new literary trend, deserves to be examined further. After all we are dealing with problems that are man-made. Our rebels concentrate their attention on social issues, particularly those concerned with the relationship between individuals, groups of individuals and institutions. It is also to be noted that "the rich Western-educated protagonist has had to take leave (of) the literary stage to make way for the neglected school-teacher, the village doctor, the poverty-stricken farmer and the underprivileged of society." ${ }^{116}$ Thus the humble, the lowly, in other words, "the people" (more in the

5 Thai P.E.N. Anthology. Short Stories and Poems of Social Consciousness. Bangkok: International P.E.N. Thailand Centre, 1984. Introduction, pp. (11)-(12).

6 Ibid., p. (12). connotation of the French word "le peuple") are those who, as is said in Thai, are "acted upon" (thuk kratham). But who are those "who act upon them" (phu kratham)? Where is "the enemy of the people"? Contemporary Thai literature is not explicit on this. It would appear that we are confronting here an "elusive enemy". One cannot ascribe this absence of clarity to the inability of these young writers to probe into the depths of social ills; nor can we speak of self-censorship alone as the major inhibiting factor. The problems besetting contemporary Thai society are so complex as to defy any straightforward, black-and-white representation. It is true that a simplistic dichotomy between the good guys and the bad guys, between the hero and the villain, persists in popular novels and television soap operas. The literature of social consciousness shuns such simplistic treatments. Its charm lies in its indeterminacy of meaning or hidden meaning. The author gives the reader a chance to fill in the gap, to think further, to seek solutions to social problems, and at its most ideal level, to bring about constructive change in real life. This may sound almost like a Brechtian social and aesthetic programme, and as I have shown in an earlier paper, ${ }^{7}$ Brecht fared very well in South-East Asian climes, and particularly in Thailand.

Let us now take into consideration some concrete examples. I shall start with Nikom Rayawa's works. Nikom is a difficult author and all the more challenging and stimulating for that. He does not communicate his message directly, but chooses to employ subtle and

7 Chetana Nagavajara. "Brecht's Relevance: a Thai Perspective." In: Brecht in Asia and Africa: The Brecht Yearbook XIV, 1989, pp. 122-131. 
complex symbols. Even the titles of his works are thought-provoking and enigmatic. The novel The Monitor Lizard and the Rotten Bough (takuad kab kop phu) (1983) is a case in point. The reader will find it hard to pin down what the monitor lizard represents or what the rotten bough stands for. The monitor lizard makes its entry right at the beginning of the novel and reappears at the end. The scene in which one of the main characters, Somkhid, chases the monitor lizard is certainly a virtuoso piece of writing, perhaps just as exciting as, or even more exciting than, those hackneyed motor chases in a gangster film! The novel treats of a lawless society, specifically the South of Thailand, in which innocent, law-abiding citizens are oppressed by "the enemy of the people" who, as usual, becomes elusive. Could it be that the author wants to denounce these destructive forces within Thai society with the term takuad, instead of resorting to the usual hia, a kindred species of reptiles also considered as creature of ill omen? But that could turn out to be a simplistic interpretation which could be far off the mark, for the final scene belies all that. Somkhid chases the monitor lizard up onto a tree, slips from a rotten bough, but is lucky enough to be able to catch hold of the monitor lizard's tail and thereby saves himself from falling flat onto the ground below. As he is dangling mid-air, he experiences a strange feeling of being one with the monitor lizard "as though he had known it intimately for a long, long time. ${ }^{18}$ Somkhid tries to stop his friend from shooting at the animal, but having failed to stop him, he murmurs to himself: "It isn't

${ }^{8}$ Nikom Rayawa. The Monitor Lizard and the Rotten Bough. Bangkok: Khon Nok Press, 1983, p. 357. (In Thai) there." 9 So killing just one takuad does not solve the problem. That remark proves perplexing even to his friend Sanong, who cannot refrain from asking: "What did he mean when he said it wasn't there?" The answer coming from another friend, Pra-wing, is equally vague: "It doesn't matter. Perhaps he was too excited." ${ }^{10}$ We are tempted to conclude that when man and the monitor lizard feel so close to each other, the people and the enemy of the people have, more or less, become one of a kind. Here the literature of social consciousness merely poses problems, and does not provide clear answers. The turmoil in human society are, in this sense, man-made, but man does not know how to get rid of them. The only way out is to seek spiritual appeasement from nature, and the author offers occasional glimpses of the external beauty of nature, which, strictly speaking, may be irrelevant to the main theme of the novel. These almost cinematographic interludes include such scene as "high mountains" and "white waterfalls tumbling down in foamy cascade."111 But the realm of beauty is not restricted to the natural domain alone; artistic creation is also given a chance to assert itself. The scene in which Somkhid chases the monitor lizard up a tree is viewed from another angle by Uncle Theng: "This is it. This is the picture that I would have loved to paint."12 The monitor lizard and the rotten bough, originally symbols of the frailty and precariousness of human life in a lawless society in dire need of drastic corrective measures, are eventually vested with an aura

\footnotetext{
$9 \quad$ Ibid., p. 359.

10 Ibid., p. 306

11 Ibid., p. 327, 348, 364.

12 Ibid., p. 358.
} 
that stamps it as an object for "l'art pour l'art." Are we to conclude that the rebel, tempered by artistic contemplation and philosophic rumination, has not become only conciliatory, but also consolatory. This may be the plight of contemporary Thai literature. Philosophic resignation often gives rise to exquisite literature of appeasement.

Nikom did not stop there. His collection of short stories The Man on the Tree (khon bon ton mai) (1984) continued to arrest the attention of the readers through its use of symbols. But the work that represents his highest achievement was High Banks, Heavy Logs (taling sung, sung nak) which appeared in December 1984 and earned its author the prestigious SEA-Write Award. Nikom has now found a new expression that suits his philosophic bent. External events recede somewhat into the background; in its place has come a series of "monologues intérieurs." The external world remains solid, static, immutable: the changes are man-made, and not always for the better. The plight of the "people" is as abject as ever, and the "enemy of the people" is just as elusive. It may be true that exploitation motivated by business interests remains rampant, but the fate that has befallen the woodcarver Kham Ngai cannot be interpreted strictly as a result of social injustice or oppression. His feeling that "he was part of the elephant and the elephant was part of him"13 is not exactly identical with the case of Somkhid and the monitor lizard, for the former case reflects the common plight of

\footnotetext{
${ }^{13}$ Nikom Rayawa. High Banks, Heavy Logs. English translation by Richard C. Lair. Penguin Books Australia, 1991, p. 134. (The translation is adequate, but rather unpoetic.)
}

fellow-sufferers, whereas the latter suggests that of co-culprits in acts of violence. Although social problems are in no way overlooked in High Banks, Heavy Logs, they are often generalized, internalized and philosophized.

All of us are born only once and die only once. What lies in between is life -- and we have to go and search that out for ourselves.

... All the shares should balance out, whether sad or happy, hungry or full, heavy or light. But most people want their share of obligations to be lighter than it should be. And even then they try to avoid burdens, unwilling to receive the responsibilities that come with the rewards. ${ }^{14}$

If the style of The Monitor Lizard and the Rotten Bough is mainly that of a descriptive narrative, marked at times by naturalistic clarity, High Banks, Heavy Logs is written in a poetic prose that occasionally rises to the level of a philosophic discourse or even that of an eloquent sermon. Some readers have found the latter work a hard nut to crack, too symbolic and too philosophic, boring even. Some cynics have remarked that to elevate social consciousness to the plane of philosophical rumination is tantamount to letting the enemy of the people slip off too easily, for metaphysics tends to look down on mundane problems from such prodigious heights that it becomes impossible to see what is black and what is white.

I have dwelt at some length on Nikom Rayawa

${ }^{14}$ Ibid., pp. 154-155. 
in order to make it clear that the literature of social consciousness did not lose its strength after 1976, but underwent, in a way, a philosophic deepening. A certain degree of sobriety was attained, whereby social problems were subjected to philosophical analysis. Thus the atrocities committed in a society in which fellow human beings prey upon one another are no longer viewed strictly as socio-political transgressions, but become philosophical cruelties, to borrow the term from Jan Kott's seminal work Shakespeare notre contemporain (1961), fit for consumption as works of art. This is one direction which the conciliation process took.

The direction taken by Nikom Rayawa is markedly different from that of the young writer Chart Kobchitti, who communicates with his public in a more direct manner without attaching much importance to hidden meaning and symbolic treatment. Chart's works could speak to the hearts of many young Thai, for they could very well identify themselves with his characters. In his works, Chart gives vent to the kind of emotional frustration shared by his contemporaries. In this respect, the young writer occupies an important place in the evolution of the literature of social consciousness. The "doyen" of Thai novelists, Seni Saowaphong, describes Chart's impact on the literary world in his introduction to Chart's first novel Dead End (chon trok) of 1980 in the following way:

... The author is moved by the plight of a group of people who occupy a peripheral place in society, struggling passively under oppressive burden from which they can never free themselves. And that is the kind of reality that we should all pay heed to, although it may be very remote from the lives of those of different social status. It may not have been a deliberate intention or strategy on the part of the writer to deviate thus from the path taken by a great number of contemporary novelists, but the motivating force must have been the emotional shock coupled with a social conscience that prompted our author to pick up just that kind of life, so insignificant as to be totally neglected, and hurl it onto his reader with the same degree of impact that had overwhelmed him emotionally and dictated his pen to write in this way. ${ }^{15}$

I have had to rely on the authority of our veteran novelist in order to emphasize the special role played by Chart Kobchitti in the history of modern Thai literature. The depiction of misery of the common people was not in itself a novelty. Some forty years earlier the novelist P. Buranapakorn had produced masterly naturalistic stories describing the lowly people in an urban setting. And more recently "Lao Kam Hom" (pseudonym of Khamsing Srinawk) had depicted the fate of the rural poor in his pioneering collection of short stories called The Sky Is No Limit (fa bo kan) (1969). But these earlier generations of writers were not received by the public in the same way as Chart was. In other words, he was a literary bombshell. The warmth and enthusiasm that

${ }^{15}$ Chart Kobchitti. Dead End. Bangkok: Ton Mak Press, 1980, p. 11. (In Thai) 
surrounded Chart's initial reception has to be explained in terms of the socio-political environment of the time. This "aesthetics of the oppressed" provided a forum on which a struggle for a better society could continue, at least imaginatively, while the real scene of action, at least in urban areas, had been emptied of living protagonists after the bloodbath of 1976. Yet this literature is highly "referential", as emphasized by Seni Saowaphong, who seems to attach great importance to its documentary value than to its artistic merit. Chart himself is sensitive to his role as a chronicler of his times, professing that "I believe that this type of stories is nothing new, but an old one, endlessly reenacted as long as slums and poverty still exist in our country ... ."16

It naturally follows that the aesthetics of the oppressed feeds on vehemence and acerbity of action. Chart is particularly adept in depicting the fate of the oppressed, so much so that he becomes oblivious of the part of the oppressors. The image of the enemy of the people is either blurred or even invisible. It is no wonder that the real cause of social ills is rarely identified. Literature falls back on philosophy, this time, on a poor man's version of Buddhist philosophy.

Bunma blames himself. $\mathrm{He}$ is angry with himself that he was born poor. He does not know why the life of a poor man like himself is always fraught with bad fortune. He only knows that life is governed by karma. He was born to atone for bad karma committed in his previous

${ }^{16}$ Ibid., p. 163.

$$
\text { life. }^{17}
$$

The Indic legacy that may have strengthened the caste system in the originating culture has been appropriated in this part of peninsular SouthEast Asia for the benefit of certain privileged people and lives on also in the minds of the lowly, resulting in a rather defeatist acquiescence in the status quo. Whether intentionally or unintentionally, Dead End becomes a philosophic blind alley that offers no liberation to the oppressed (whereas real and enlightened Buddhism is a philosophy of liberation.) The enemy of the people has eluded again, while the people are stuck in a perpetual dead end.

It is worth noting that Chart may have realized this shortcoming, and in his masterpiece The Judgement (kam phiphaksa) (1981) he paints a much clearer picture of the enemy of the people. The headmaster takes over the role of the vilain, representing "the others" in Chart's own interpretation of the Sartrian dictum: "L'enfer, c'est les autres". (I have elsewhere analyzed the Thai writer's debt to Sartre and Camus.) ${ }^{18}$ The popularity of The Judgement is probably not too difficult to account for, since, in spite of its various technical blemishes and its occasional lapses into unnecessary grotesquerie, the people and the enemy of the people are pitched against each other in a fairly straightforward manner. The doctrine of karma, accepted so uncritically by the main character in Dead End, is reinterpreted by Fak in The Judgement. One

\footnotetext{
${ }^{17}$ Ibid., p. 152.

${ }^{18}$ Chetana Nagavajara. "Spatial Concentration and Emotional Intensity," op.cit., p. 292-296.
} 
can easily see how the philosophy nurtured on the central plain of the Chao Phraya has been enriched by the philosophy from the Left Bank of the Seine.

Was it his karma, his fate? When had he ever done anyone a bad turn? How had it come about when he had never killed, not even a fish, never stolen money or property from anyone, never committed adultery or taken advantage of anyone's daughter, never spoken badly of anyone or lied to anybody. Alcohol-nobody could say he had ever touched it. He couldn't even bear to look at it. He had always practised the five precepts, so why should he have to suffer this retribution? "Or is it karma from some previous life time?" He couldn't believe that. There was only one thing he could really believe: the suffering he was going through was a direct result of other people's actions. ${ }^{19}$

This is a liberation attempt on the part of the lowly, which already smacks of a certain sense of philosophical rebellion. In the search for the enemy of the people, even Buddhist monks cannot escape unscathed: they too have been

${ }^{19}$ Chart Kobchitti. The Judgement. Translated by Laurie Maund. Bangkok: Thammasat University Bookstore, 1983, p. 39. (As with High Banks, Heavy Logs, this translation is rather bland and does not quite match the poetic acuity of the original.) "judged." The abbot is no help to the poor and the humble, ever ready to consort with the privileged and the rich. "The others," whatever their social status, are no longer accepted unconditionally. If no tribunal in this life can render justice to the people, the oppressors can still be judged in the nether kingdom! The new rebellious spirit is possible because Buddhism has now been vested with a social conscience.

$\mathrm{He}$ had committed three wrongs during his lifetime: he had killed the dog, lied to Luang Pho and drunk alcohol. If he died he would probably have to go to hell because of these wrongs. But the actions which other people had done against him were much more and worse than what he had done, and if he were to go to hell when he died, he would be sure to meet many people that he knew... and he would wait for them. ${ }^{20}$

When all is said and done, The Judgement is an important milestone in the development of the literature of social consciousness. Although Fak, the protagonist of the new rebellion, may be defeated, his enemies, at least in the eyes of the reader, have not remained immune to moral "judgement." Yet, the reader still does not have the answer as to the real cause of social injustice. The law of karma no longer explains Fak's plight in a hostile society. Chart, in this novel, is intent upon creating a strong emotional impact on his readers through sarcasm, grotesquerie and acerbity, which at times go to excess. Such tendencies become even more apparent in his collection of short stories

20 Ibid., p. 257. 
entitled $A$ Knife for Everyone (meed pracham tua) (1983), in which violence reaches its paroxysm in acts of cannibalism. When an author does not know how to distinguish between philosophical cruelties and physical cruelties, he is bound to be caught in an artistic dead end. In the final analysis, his brand of literature of social consciousness seeks to shock the public out of lethargy by committing suicide, so to speak. As literature it may succeed in arousing the emotions of its readers, but the effect may not be long-lasting. I am personally inclined to agree more with Bertolt Brecht that an art which aspires to create social consciousness or to bring about social change must appeal also to reason and intellect. When all is said and done, it appears that our young author has unwittingly coerced himself into a non-combative position and contented himself with lamenting the helpless and hopeless fate of his own brethens.

It is not surprising that some readers find Chart Kobchitti's pessimism too unmitigated and uncompromising. They would rather opt for a different kind of pessimism which does make room for human dignity and would readily hark back to the novel The Village Teacher (khru ban nok) (1978) by Khamman Khonkhai, which was also immensely successful in its film version. The novel offers a penetrating analysis of a corrupt society in which murderous business tycoons annihilate honest and courageous citizens. Unlike Nikom Rayawa, Khamman identifies the enemy of the people. In an arresting story manipulated with a great narrative skill he creates a memorable character in the person of an idealistic school-teacher, who almost single-handedly fights against illicit deforestation. Naturally, the village teacher is crushed, but his death is presented in such a dignified way as to rival a great tragedy. No doctrine of karma is cited to explain the defeat of the people, no lamentation over a lost cause, no philosophic rumination, but a realistic appraisal of the situation that the fight against social evil will be a long one and that the death of one man will awaken many more idealistic fighters. It cannot be denied that the enemy of the people has eluded again, but there are grandeur and dignity in the act of fighting against the evil force in society. The defeat of the village teacher does not represent a defeatist stance, but a defiance against the enemy of the people. This is a rare instance whereby the rebellious author (and a sober and mature rebel!) knows exactly what he is rebelling against and does not need to shift from an aggressive stance to a conciliatory one, for he has always kept a cool head, prepared himself for a long fight and looked to the future with a certain measure of confidence.

Not many of Khamman's contemporaries were blessed with the same degree of sobriety. When we turn to poetry, we shall see that this was a vehicle of social and political protest in which frontal attacks on the enemy of the people were made without much reservation. That the powers-that-be chose not to crack down on these rebellious authors speak well for their tolerance (although some cynics maintain that they were either illiterate or did not think that literature could do much damage!) In this connection, we shall have to take into consideration Khomthuan Khanthanu's two volumes of poetry that enjoyed immense popularity among the readers, namely Consciousness of a Rebel, (samnuk khabot) (1980) and Drama on a Vast Arena (natakam 
bon lan kwang) (1982), the latter being crowned with the prestigious SEA-Write Award. Khomthuan does not mince his words and never hesitates to identify the enemies of the people. Even the Buddhist religious order is not spared. $^{21}$ The poet is ready to act as a voice of conscience to society, and in particular instances also to his fellow-writers. The following poem "To My Journalist Colleagues" (dae puan nangsue phim) is typical of the poet's critical stance.

You look so proud and resolute, but money can bend you any time.

Seeing bandits fully armed, you turn speechless and confounded. ${ }^{22}$

Yet one cannot help feeling that Khomthuan sees things mainly in opposites and occasionally lapses into a black-and-white depiction of contemporary society. Urban life is condemned, whereas rural life is praised for its blissful innocence. The lead poem "Drama on a Vast Arena" (from which the collection takes its name) is explicit in its radical condemnation that "on every street of Bangkok, packs of wolves prey on Northeasterners. ${ }^{1123}$ Certain readers may feel that Khomthuan's radical criticisms of Thai society may go a little too far,

${ }^{21}$ Khomthuan Khanthanu. Consciousness of a Rebel. Bangkok: Ko Phai Press, 1980, p. 153-155. (In Thai)

${ }^{22}$ Khomthuan Khanthanu. Drama on a Vast Arena. Bangkok: Ko Phai Press, 1982, p. 31. (In Thai)

${ }^{23}$ Ibid., p. 67. (The Northeast is the poorest region in Thailand, and Northeasterners flock into the metropolis to look for jobs.) but they cannot deny that he examines social problems with remarkable acumen. Besides, his mastery of Thai language and prosody does carry him to great poetic heights. But what makes Khomthuan a poet that no one can ignore is his intellectual and moral honesty: he is ready to admit that the enemy of the people is among us, or one of us, (as we have seen above in the poem "To My Journalist Colleagues"). Nevertheless, he knows that he is in no better position than his colleagues when it comes to initiating concrete changes or paving the way for the victory of the people. Poetry has, of necessity, to become a declaration of ideals. His "Manifesto of a Writer" is very much a forward-looking statement:

Let us forge a fighting spirit, And not be afraid of those scoundrels in the military and police forces.

One day their evil will manifest itself.

Against those who oppress the people,

We shall rise in a rebellion.

This shall be our kind of virtue. ${ }^{24}$

The enemy of people may have eluded, but only temporarily, for the people are willing and prepared to engage in a long struggle. Very few writers and poets have had the audacity to call out who the enemies of the people are. Khomthuan still continues to write in an almost similar vein about social injustice and the oppressive forces in Thai society. The rebel does not want to give up too easily his rebellious cause, but it would appear that few

${ }^{24}$ Ibid., pp. 75-76. 
people read him nowadays. His prolixity and his perseverance are admirable, but his poetic acuity has diminished over the years. How long can "angry young men" remain young and poetically effective is a question for which there exists no ready-made answer.

It is to be observed that the literary works we have examined so far deal with social problems as phenomena and do not give serious consideration to their causes. Are we to demand from our writers and poets to assume the function of social scientists, or should we expect of literary works to be merely thoughtprovoking? After all, it is not all that easy to determine the causes of social ills. Let us now turn to some works which address the causes of social problems. The literature of social consciousness very often takes poverty as its major theme, but we cannot always be sure whether poverty is the cause, or the effect, of the malfunction of the society. I would like to cite as an example the short story Onn (1980) by Warangkhi (which was awarded a prize by the Thai P.E.N. and was taken up in The Thai P.E.N. Anthology.) The story deal with the plight of a young countrygirl who has been raped by a policeman and is faced with the dilemma whether to take the case to court or to accept a handsome monetary compensation. In the end she decides to take the money. Are we to interpret poverty as the cause or the effect of the problem? The author more or less tries to suggest that it is the cause, that is to say, poverty determines her decision. But viewed from another angle, poverty is the result of greater evils that plague modern Thai society, namely inhumanity and immorality. The matter is further complicated by the fact that, by accepting the compromise to settle the matter out of court, the young girl too readily exculpates the culprit and thereby, unwittingly perhaps, perpetuates lawlessness and immorality. The enemy of the people eludes, because the people become too conciliatory. The story that, at first, sets out to identify the enemy of the people, in the end, does find a coculprit from among the people themselves.

Another short story that merits our attention in this connection is "Nightfall on the Waterway" (1978) by Ussiri Dhammachote from the award-winning collection Khunthong, You Will Return at Dawn (khun thong, chao cha klab mua fa sang) (1978). Here again poverty and moral choice are locked in a conflict: the protagonist is a poor melon vendor who discovers a dead body with a gold bracelet and wavers for some time whether to take it, before finally deciding to commit the "immoral" act. The "monologue intérieur" preceding that decision is deliberately presented as a "materialistic" justification.

... Even if the fortune wasn't all that large, it would still be worth more than what he was paid for his boatload of watermelons ...

$\mathrm{He}$ was elated by visions of his care-worn wife wearing the lace blouse she had so long waited for; perhaps he would even buy her one of those prettily coloured (skirts) from the North to go with, and he would get clothes for their child and for himself. For the first time he would enjoy the happiness of spending without twinges of pain from parting with hard-earned money ... The happiness that would 
light up the drained face of his wife and the eagerness that would shine in his child's eyes, short-lived and transient though they might be, were blessings as precious to his joyless life as a shower to a drought-parched paddy field. $^{25}$

So the economics of destitution has the upper hand of moral propriety! The author remains ambiguous. If poverty is the enemy of the people, it is an enemy that cannot easily be overcome. In the final analysis, who is enemy to whom? "He no longer cared where (the corpse) came from or whether the parents would learn of their child's fate. The little human tragedy receded into the back of his mind where only a trace of it lingered." 26 That "a trace" of the "human tragedy" still "lingered" on is a good sign that the man was still capable of repentance, but that was "only a trace," and this should give us pause. In other words, he only repented a little (the original Thai version contains the phrase "a little"). The enemy of the people was probably not an external enemy after all, and the people, beset with dire poverty, were beginning to forgo all moral considerations. Social problems have been internalized again. We are more or less back to the position taken by Nikom Rayawa in The Monitor Lizard and the Rotten Bough. The protest against social injustice has taken on a conciliatory tone.

It must have become evident by now that most

${ }^{25}$ Ussiri Dhammachote. "Nightfall on the Waterway". In: Ussiri Dhammachote. Khunthong, You Will Return at Dawn. Translated by Chamnongsri Rutnin. Bangkok: Ko Kai Press, 1987, p. 157.

${ }^{26}$ Ibid., p. 158. of the works analyzed so far reflect distinct ideological directions which the authors wish to take and, in some cases, to share with his readers or even to impose upon them. Objectivity may not be the kind of virtue with which our literature of social consciousness has distinguished itself. Not that there has been no serious effort to espouse objectivity as an artistic principle; one only has to think of Khamsing Srinawk's short stories, already mentioned above, in which our sympathy for the poverty-stricken rural people is engaged without our feeling of being guided along by the author. But the supreme example of artistic objectivity achieved by any author of this period is Kampoon Boontawee's A Child of the Northeast (1975-76). Obviously, the author has imposed a rather strict discipline upon himself in the sense that the depiction of the miserable existence of the Northeastern people is carried out in a non-dialectical way, and that no accusation is ever made as to who the oppressor is, and who the oppressed. The section which seems to best represent the author's profession of faith begins with a question posed by the abbot to the child Khun: "Who and what do you hate most?". The answer is: "I hate the sky, sir." The harsh admonition by the abbot may be far in excess of the boy's guilt, for he is caned by the monk who gives him the final moral lesson: "... the sky never hurts anybody. Only people can really hurt people."127 If this is the philosophical framework set by the author, the people can no longer ascribe their sorry plight to an external cause, human or non-human. (Only those readers sensitive to the fine nuances of

${ }^{27}$ Kampoon Boontawee. A Child of the Northeast. Translated by Susan Fulop Kepner. Bangkok: Editions Duang Kamol, 1988, pp. 111-112. 
contemporary Thai may catch the subtle irony embedded in the word "sky".) In other words, nobody is to blame anybody. A Child of the Northeast thus reads more like a long recipe fit for Northeasterners living in dire poverty. Yet one cannot help feeling that the destitution, which plagues the daily life of the protagonists who have to undertake long journeys in search of the barest minimum of food, should provide ample ammunition for a most austere social criticism as well as ample material for a heartrending narrative. But our author never loses his way, and this odyssey of hunger-ridden rural poor who refuse to give up hope becomes an incomparable understatement rarely found in modern Thai literature. Expressed in Western literary terms, one could perhaps say that $A$ Child of the Northeast is a novel that Gustave Flaubert would have loved to write but never did write. The enemy of the people has no chance to appear, and these good-humoured Northeasterners accept their fate, not stoically, but in a remarkably natural way that would disarm any social critic equipped with the notion of "the enemy of the people". The question remains whether such an "epic" treatment (in the Brechtian sense) of an explosive material, somehow or other, manages to drive the attentive reader to further critical reflections and to think out possible corrective measures of his own accord. The author would probably react that that was not his intention.

The objectivity achieved by Kampoon Boontawee may not be the kind of ambition shared by his contemporaries. It would appear that the majority of them move in the opposite direction. Objectivity in the realm of the arts could be misconstrued as a sign that writers and artists have already given up their fights against the enemy of the people. On the whole, our contemporary writers and poets are ready to assume the role of social critics, and in this respect their expressive power does match their social consciousness. Let us turn to the plight of Bangkokians, which is no better than that of their fellows in the rural area. Suchit Wongthed's Sepha on the Deluge That Swamps a Street Vendor (sepha nam tuam hap re) (1983) is a work with more than just a documentary value, for the poet does not view the inundation of Bangkok simply as a natural phenomenon. The very title suggests that the poor people of Bangkok are submerged under a flood of sins:

Water is infested with sperm and gonorrhoea;

Water polluted by the sins of man; Poisons washed down from empty talks in Parliament;

And tears shed by us, vagabond balladiers. ${ }^{28}$

The last line is an explicit statement that the poet does not propose to maintain an objective stance vis-à-vis the fate of the people. Sepha on the Deluge That Swamps the Street Vendor tells the story of a destitute street vendor, married to a low-ranking policeman, who, in carrying out his duty, has to drive the wife away from areas on which vendors are not allowed. They quarrel, and the wife is fatally

${ }^{28}$ Suchit Wongthed. Sepha on the Deluge That Swamps a Street Vendor. Bangkok: Chao Phraya Press, 1983, p. 17. (In Thai) Sepha is a traditional verse narrative originally chanted, the most famous being the lengthy Khun Chang Khun Phaen. Modern poets have abandoned long stories and have used the sepha to address topical issues or events. 
knocked down by a bus. This is how the wife argues against the law-enforcement of the policeman.

What about those corrupt officials in ministries

Who misuse tax payers' money?

Why doesn't the police arrest them

Instead of cracking down on poor street vendors?

Those high officials in ministries

Are having a really grand time,

Having subordinates to pamper them,

And having no idea how our children suffer? ${ }^{29}$

So the flood makes people more conscious of the injustice within Thai society. In order to alleviate the sufferings which have been aggravated by the flood, the people organize a boat race. The poet exhibits great mastery both in terms of virtuosity of form and acuity of the soeial message. At one point the boat race is interpreted as a philosophic reminder.

Our wise men explain

That this boat race predicts

That karma determines the end of man.

When a boat leaks and sinks,

This indubitably is in accord with Buddha's teachings

That a life not properly lived will meet with danger,

${ }^{29}$ Ibid., pp. $79-80$.
Just like a boat that capsizes before reaching the finishing line. ${ }^{30}$

This "deluge" is a lesson to everyone, political leaders (whose names are affixed to the boats) as well as lowly people. Faced with a natural disaster, the demarcation line between the classes becomes obliterated. In the final analysis, class conflicts disappear. The death of the street vendor comes as an accident and has no direct link with the socio-political problems treated elsewhere in the work. Artistically speaking, this abrupt ending is touching without being sentimental. The readers almost take it as a result of the vendor's own karma, and forget the socio-political issue posed earlier by the poet. Philosophical resignation provides the enemy of the people with another chance to elude!

At this juncture, a more fundamental question has to be raised. When we speak of "the enemy of the people", are we to think only of real people, of a social class or an institution? When all is said and done, the most powerful enemy of the people is none other then their own uncritical attachment to certain values and beliefs. Khamsing Srinawk has dealt with these false values in his collection of short stories mentioned above. But the most impressive treatment of this problem is to be found in a short story by Ussiri Dhammachote called "The Bondage" (1978). It deals with the fate of two very close friends engaged in a duel, which turns out to be a double suicide, a deliberate liberation from the yoke of servitude. The two friends, serving two brothers who happen to fall out of each other, are locked in a dilemma in

\footnotetext{
${ }^{30}$ Ibid., pp. 52-53.
} 
which their loyalty to their respective masters forces them into enmity. The masters, plagued by selfishness and cupidity, demand of them absolute allegiance, and having been brought up in a traditional society in which servants must be ready to die for their masters, they never think of rebellion in terms of disobedience. ${ }^{31}$ The only way out is suicide, a double suicide, carried out in a dignified, manly manner, a duel at sunrise. Yet they have managed to stage a rebellion on a different front. Their generation shall be the last to adhere to traditional values and beliefs that are not grounded on rational and humane considerations. They have seen to it that the generation of their children shall grow up in a new environment, free from categorical acceptance of authority and uncritical subservience. The old Thai saying "When elephants fight, the grass is trampled" can no longer be accepted unconditionally, for the new generation has been liberated from outmoded codes of conduct. The fight against the enemy of the people is thus no longer to be carried out on conventional fronts. In an almost Buddhistic terms, Ussiri has internalized this war of liberation by relocating it into the mind of man. The new generation will undergo an education or a re-education that awakens to the new spirit of democratic enlightenment. This is what literature can do, serving a new "education of the human race" (to borrow the term from the German philosopher and poet Gotthold Ephraim Lessing), and it is to be an education in the broadest sense of the word. The rebel has become a philosopher, once again.

${ }^{31}$ Ussiri Dhammachote. "The Bondage". In: Ussiri Dhammachote, op.cit., p. 143. (The exact translation of the title would be "And the grass is trampled," referring to the Thai saying "When elephants fight, the grass is trampled.")
In the final analysis, the fight against the enemy of the people in Thai literature of social consciousness has assumed the character of an endless pursuit of an ideal. Writers and poets may misjudge social and political phenomena; they may turn out to be bad prophets. But are we to gauge the value of literature in the same way as we count on the validity and reliability of the social sciences? People continue to appreciate Naowarat Pongpaibun's poem "Lullaby for My Friends" (phleng klom puan) as a work of literature, although they know full well that those high hopes set out by the poet have not materialized.

Though the road is dark and long, we shall push ahead,

A candle that lights up Thailand, ready to burn itself.

We shall walk arm - in - arm, dauntlessly engaged in the battle.

The bells shall toll, keeping you company, my friends.

When they start shooting, we shall line up to brave them,

To fulfil the people's ideal and declare our victory. ${ }^{32}$

The poem was dated 14 October 1975 and was written to commemorate the second anniversary of the "October Revolution" of 1973. With the benefit of hindsight, we know what happened in October 1976; we know the fate of the people in "Black May" 1992, and it would be too easy to

32 Naowarat Pongpaiboon. "Lullaby for My Friends". In: Naowarat Pongpaiboon. Mere Movement (phiang kwam kluan wai) (original Thai version). Bangkok: Praphan Sarn Press, 1976, p.49. The selection in the Thai-English bilingual edition of Mere Movement (Bangkok: Ko Kai Press, 1980) does not contain this particular poem. 
jump to the conclusion that literature has contributed nothing, or little, to bringing about a constructive change. Yet the very realization that the road to the future "is dark and long" is no small contribution to the awakening of a national consciousness. The rebel may have become conciliatory, but he has not given up his rebellious mission altogether.

In conclusion, we may have to admit that the conciliatory tendency is a characteristic that runs through Thai literature from the earliest period to the present. To pitch "the people" against "the enemy of the people" may be the kind of dialectical thinking that is not germane to Thai philosophy of life. The belief that "l'enfer, c'est les autres" often gives way to the discovery that "l'enfer, c'est le moi" or even "l'enfer, c'est moi". Traditional Thai literature bears ample testimony to that conciliatory potential within Thai culture. The epic Taleng Phai by Prince Paramanuchit from the late $18^{\text {th }}$ century does not depict the Burmese as our arch-enemy at all. The Crown Prince of Burma is a worthy opponent to the Thai King Naresuan, and we find him dignified, likable and worthy of our sympathy. Literature is an area for reconciliation that may not be possible in the world of reality. The Thai version of the Indic Ramayana, known in Thai as Ramakien, no longer represents a clear-cut conflict between good and evil, and the original evil character Ravajna becomes, in the Thai version, Thotsakan, a favourite with the Thai audience when presented as a mask drama. Needless to say that Rama in the Thai version pales beside the robust Thotsakan who has been acclimatized in the salubrious environment of the land of smiles and has acquired, in the meantime, many humane attributes. On the
Thai stage as well as in Thai literature, even good and evil are not presented in a black-andwhite manner. Contemporary Thai literature cannot depart too far from its traditional roots.

So our rebels cannot remain rebellious for too long. Yet the Marxian tutelage has not been altogether futile, for it has sharpened their social consciousness. Conciliation is not to be interpreted as a renunciation of responsibilities. With some of our writers and poets, it may be taken as part of the process of intellectual maturation. The major achievement of the conciliatory rebels lies in their realization that the road to an ideal society is a long and arduous one. They have said so, and have said it with beauty and conviction. ${ }^{33}$

${ }^{33}$ The present article was commissioned by the Social Science Research Council (SSRC), U.S.A., for a volume on South-East Asian Literatures, a project later abandoned by SSRC. It is an updated version of a lecture in Thai under the title "satru thi luen lai" (The Elusive Enemy), delivered at Silpakorn University, Bangkok, on 30 July 1986, and published for the first time in the magazine Thanon Nangsue (Bookpath), August, 1986. All translations, when not otherwise stated, are mine. The spellings of proper names follow the transliteration system of the Royal Institute, except in those cases in which English translations exist and the names have been spelt differently by the respective translators. 